\title{
Conflito, Resignação e Irrisão na Música Popular Brasileira: um estudo antropológico sobre a Saudosa Maloca, de Adoniran Barbosa. Por que as Canções têm Arranjos? ${ }^{1}$
}

\author{
Rafael José de Menezes Bastos² \\ Universidade Federal de Santa Catarina, Santa Catarina, Brasil \\ E-mail: rafael@cfh.ufsc.br
}




\section{Resumo}

Trata-se de um estudo sobre o samba Saudosa Maloca, de Adoniran Barbosa, por meio da análise de sua obscura primeira versão (de 1951), com arranjo de Nelson Miranda, tendo como cantor o próprio compositor. Esse arranjo é brevemente contrastado, sobretudo através da letra, com aquele dos Demônios da Garoa (de 1955), de autoria do próprio grupo, que transformou o samba num grande sucesso. O primeiro arranjo é marcado pela tristeza e pela dor, construídas por uma musicalidade de lamentação e de resignação. A letra da Maloca narra um encontro dramático de três sem-tetos com o establishment imobiliário na São Paulo dos anos de 1950. Esses anos são caracterizados pelo ufanismo econômico, pela reinvenção da paulistanidade e pelas retumbantes comemorações do $4^{\circ}$ Centenário. O segundo é marcado pela jocosidade e pelo desdém, fabricados por uma musicalidade da irrisão. O estudo busca reconstituir os modelos nativos de compreensão da canção, dando especial atenção às problemáticas do arranjo e das maneiras de cantar e de tocar.

Palavras-chave: Adoniran Barbosa. São Paulo. Arranjo. Maneiras de Cantar e de Tocar. Modelos Nativos de Compreensão da Canção.

\section{Abstract}

This is a study about the samba Saudosa Maloca, by Adoniran Barbosa, by means of an analysis of its obscure first version (of 1951), with arrangement by Nelson Miranda, having the proper composer as singer. This arrangement is briefly contrasted, over all through the lyrics, with that one by the Demonios da Garoa (of 1955), that transformed the samba into a great success. The first arrangement is marked by sadness and pain, constructed by a musicality of lamentation and resignation. The lyrics of Maloca tells a dramatical encounter involving three homeless people with the establishment in São Paulo during the 1950's. These years are characterized by economic overoptimism, by the reinvention of paulistanidade and the thundering commemorations of the 4 th Centennial of the State of São Paulo. The second is marked by jocosity and disdain, and is constructed by a musicality of derision. The study aims to reconstruct the native models of song comprehension, giving special attention to the questions of arrangement and of manners of singing and playing.

Keywords: Adoniran Barbosa. São Paulo. Arrangement. Manners of Singing and Playing. Native Models of Song Comprehension. 
Para Beth Travassos, em memória.

Escrever errado é a coisa mais difícil que existe. Se não for feito do jeito certo, vira piada, deboche.

(Adoniran Barbosa)

\section{Introdução}

$\mathrm{O}$ conceito de arranjo parece apontar para uma natureza essencialmente aspectual de cada arranjo de per se em relação àquilo que pode ser chamado de material básico ou pré-existente - que pode assumir as mais variadas formas: uma melodia, tema, peça vocal e/ou instrumental - e em relação aos demais arranjos do mesmo material. Um arranjo em particular salientaria, revelaria e/ou inventaria um universo de aspectos, modos, maneiras de ser desse material, trazido à tona pelo arranjador e pelos músicos que o executam. Tudo se passa como se esse material (no presente caso, a própria canção solo, Saudosa Maloca, de Barbosa, aquela que por primeiro brotou de sua lavra, anterior, pois, ao arranjo de 1951) fosse a versão de referência das demais, para uma vez mais aproximar-me das formulações de Lévi-Strauss 3 . Pretendo aqui avançar na direção de descortinar a natureza dessa aspectualidade, através da reflexão sobre uma cadeia de conceitos pertinentes ao conceito de arranjo. Entendo que os conceitos de versão e interpretação não podem faltar a essa cadeia.

Como notou Aragão (2001) ${ }^{4}$, as definições correntes de arranjo no universo da música popular brasileira sofrem de forte indefinição conceptual, estando por demais calcadas no senso comum. No caso, por ele estudado - arranjos de Pixinguinha de 1929 e 1935 - essas 
definições, por outro lado, se transformam de maneira mais ou menos radical de acordo com o contexto histórico e o campo de seu emprego. Aragão no texto em tela não tem como fim buscar uma compreensão propriamente analítica do conceito em consideração. Isso se confirma em sua contribuição posterior sobre a temática, parte da coletânea de textos que acompanha a coleção de arranjos, também de Pixinguinha, mas das décadas de 1940-50, veja Leme (2010).

Bessa (2010), cujo estudo inclui a análise de arranjos também de Pixinguinha, dos anos 1920-30, é diferente a esse respeito. Baseando-se em Szendy (2001), ela procura precisar sua conceituação analiticamente, optando por equacioná-la com a noção de escuta desse autor. Diz ela (2010, p. 188, grifo meu): "[...] o arranjo musical tem como principal característica 'fazer escutar $\underline{\mathrm{como}}^{\prime}$ e, dessa forma, tornar pública uma percepção particular, única, qual seja: a do arranjador". Note-se nessa concepção seu centramento na aspectualidade - conforme o como como percepção (do material pré-existente) por parte do arranjador, os músicos executantes sendo, por outro lado, desconsiderados.

Especificamente para o domínio da música erudita, Boyd (2006, tradução minha) conceitua arranjo como “[...] qualquer peça de música baseada em ou que incorpore material pré-existente". Evidentemente que esta definição é problemática, o centro de seu problema localizando-se na oposição que faz descortinar - mas não elabora - entre os conceitos de arranjo e composição. Um arranjo seria, assim, nos termos dessa definição, tudo aquilo que uma composição não é, ou seja - e aí o cerne do problema dessa definição - tudo aquilo que não é considerado como obra autoral (a saber, composição, diferentemente de arranjo)).

Se a definição de arranjo de Boyd, para o campo da música erudita, é problemática, por não considerar suas conexões com o universo da autoria, a de Schuller (2006), pensada para o âmbito do jazz, não o é menos. Schuller, por um lado, defende um conceito restrito de arranjo, praticamente idêntico ao de Boyd. Por outro, adota uma acepção tão ampla na qual tudo pode caber:

[...] até certo ponto - diz ele -, toda "performance" de jazz constitui uma forma de arranjo, na medida em que é improvisada e constantemente renovada; quer dizer, os 
"performers" rearranjam o material básico a cada nova variação e forma. (SCHULLER, 2006, tradução minha)

É muito interessante nessa definição sua ênfase no papel dos músicos executantes, que, na maioria das vezes, é apagado nas conceptualizações de arranjo.

Em um texto de $1996^{5}$ onde estudei o Feitio de Oração, de Vadico ${ }^{6}$ (música) e Noel Rosa (letra),sugeri que a identidade da canção, no caso da música popular, é dada pela música: sua letra pode ser modificada, até por esquecimento do cantor e de maneira, mais ou menos, radical, cancelada ou substituída por um arranjo instrumental, mesmo por um assovio ou canto do tipo "nã-nã-nã", ou não entendida - digase: linguisticamente - caso clássico das letras em línguas estrangeiras não compreendidas por quem canta e/ou pela audiência.

Ali mesmo, porém, adicionei que isso não significava dizer que a letra de uma canção não tem importância para a sua fruição e compreensão, "[...] já que o esquecido ou o incompreendido são tão fundantes quanto o lembrado ou o entendido" (1996, p. 164). Recordo que no texto a hierarquia entre música e letra se colocava tão somente no plano da identidade de uma canção vis-à-vis a de outra. Conclui minha reflexão dizendo que "[...] uma canção é já em sua substancialidade, e mesmo que feita por uma só pessoa, um diálogo [...]", termo que ali usei no sentido de Bakhtin (1986) ${ }^{8}$. Continuei, “[...] estranho diálogo este - intersemiótico, acrescento agora -, que já de começo rompe com a unidade autoral, desenhando-se na polifonia mais congênita". Adicionei, tancredianamente: "Há uma luta, de foice - no escuro da canção". (1996, p. 164)

Naquele mesmo texto, embora tenha levado em conta o arranjo original do Feitio (de 1933, possivelmente de Vadico), não tomei o arranjo, enquanto tal, como objeto de estudo. Pretendo agora fazer isso, de forma, porém, apenas medianamente detida, levando em consideração, de maneira estratégica, a análise sobre as questões interpretativas, especialmente estilísticas, postas pela execução da canção, no caso, através do primeiro arranjo (de 1951) do samba Saudosa Maloca, cantado por Adoniran Barbosa (1912-1982) ${ }^{9}$, brevemente contrastado, 
através da letra sobretudo, mas também, de maneira breve, da música, com aquele dos Demônios da Garoa (de 1955).

Vale começar considerando como a palavra arranjo é dicionarizada em português. No Dicionário Houaiss, assim ela é registrada ${ }^{10}$ : “[...] adaptação de uma melodia ou composição a outra estrutura de harmonia, de textura ou de timbre". Ao final dessa definição,acrescenta-se: "Obs.: cf. orquestração", os sentidos que ele levanta para orquestração sendo:

1. Rubrica: música: "[...] ato ou efeito de orquestrar; modo pelo qual as partes de uma orquestra estão combinadas, equilibradas, arranjadas entre si. Obs.: cf. arranjo.

2. Rubrica: música: arte de compor para cada instrumento da orquestra; adaptação de uma melodia ou composição a uma estrutura orquestral".

A definição presente no Houaiss, com o adendo sobre orquestração, parece dar conta de uma grande parte dos casos da relação entre composição (canção, melodia, tema, etc.) e arranjo na música popular no Brasil, onde o compositor (tipicamente um cantautor ou cancionista) produz canções, em parceria ou não com outro(s) compositores e/ou letrista(s), via de regra originalmente acompanhadas por um instrumento harmônico (violão, piano, acordeom). São essas canções que constituirão a base, o material básico dos arranjos.

Diferentemente do que coloca Szendy - que, como visto, centra sua concepção no arranjador e naquilo que ele pretensamente percebe, escuta - trabalharei aqui na direção de também abranger no universo do arranjo tanto os músicos (incluindo o cantor) quanto o plano da recepção por parte da audiência. Farei isso, entretanto, de maneira muito menos que exaustiva. Essa abordagem do conceito de arranjo parece-me mais adequada na medida, no primeiro caso, em que tematiza também as maneiras de cantar e tocar, um tema nobre e originário da Etnomusicologia (Herzog, 1928, 1936), de grande interesse no plano interpretativo. No segundo caso, na medida em que um enfoque que busque compreender a dialética dos planos de produção e consumo da música - do arranjo, aqui - coloca-me uma vez mais 
próximo às formulações também de Marx, tipicamente conforme sua célebre discussão com Stuart Mill nos Grundrisse.

Os dois arranjos que estudarei a seguir - o segundo, como disse, brevemente e como elemento de contraste em relação ao primeiro -são em tudo por tudo bem diferentes ${ }^{11}$. O primeiro é de autoria de Nelson Miranda, diretor do conjunto que leva o seu nome e que executa o arranjo. Esse arranjo envolve um cantor (o próprio Barbosa)e um clarinetista solistas, um setor de cordas dedilhadas, outro de percussão (violão de seis cordas, cavaquinho, pandeiro, tam-tam) e um coro misto feminino, em uníssono ${ }^{12}$. O segundo arranjo, ao que tudo indica dos próprios Demônios em sua formação de 1955, envolve em coro os então cinco integrantes do grupo - umas partes em uníssono, outras com abertura de vozes - e os instrumentos tocados por eles: violão, violão tenor, tam-tam, afoxé e pandeiro ${ }^{13}$.

Segue uma transcrição de trabalho do primeiro arranjo: 

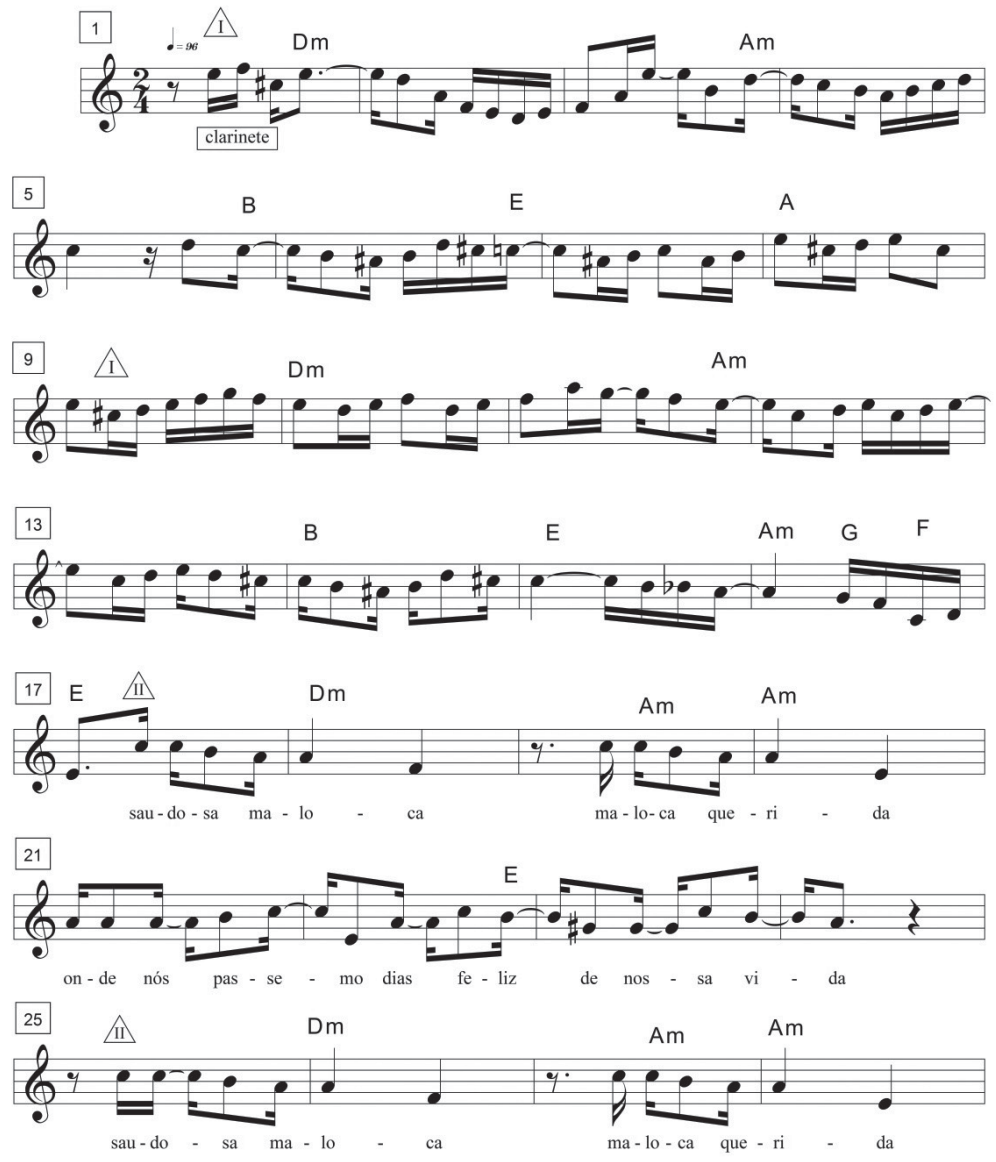

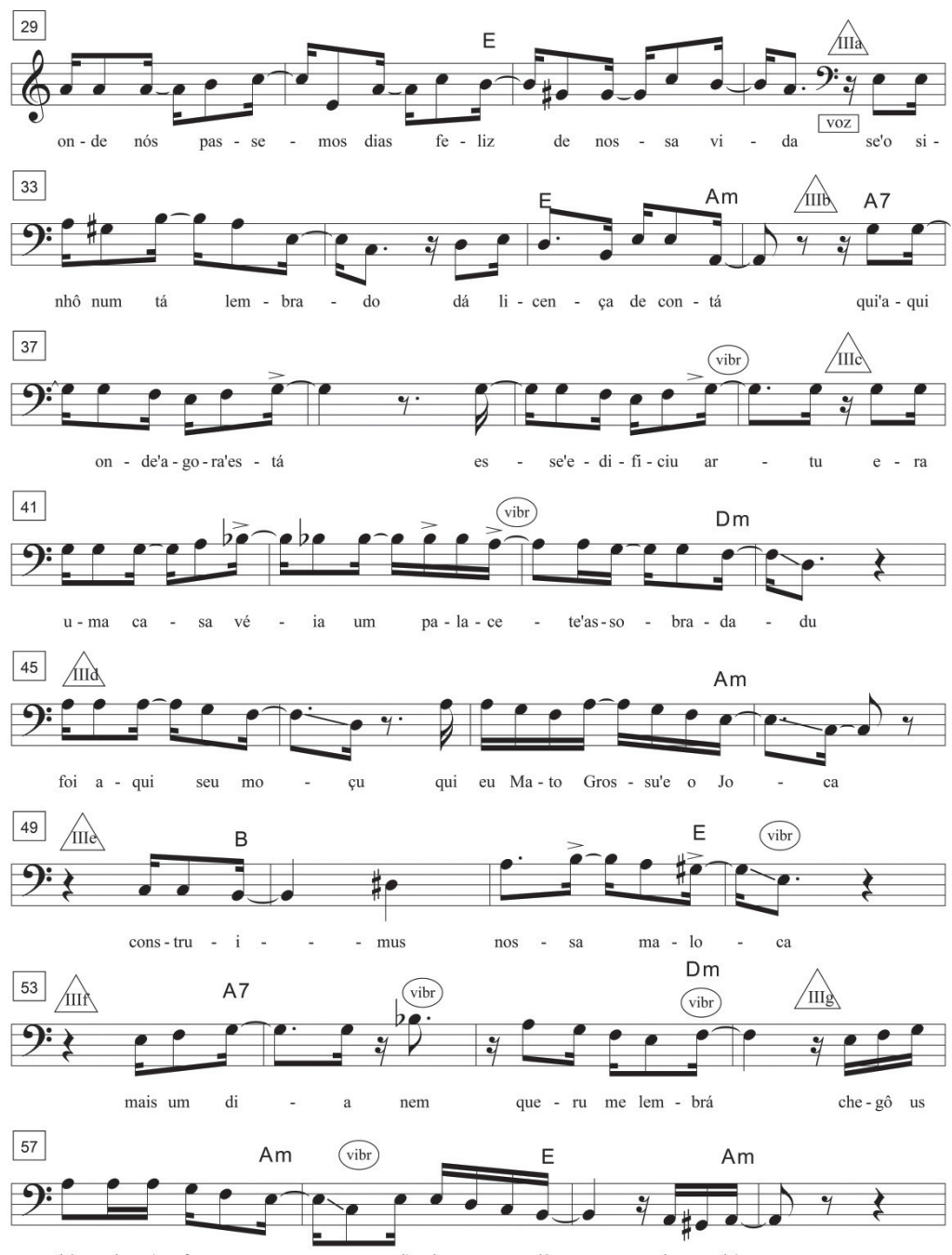

hô - mis co'as fer - ra - men - ta qui'u do - nu man-dô der - ru - bá

$-2-$ 

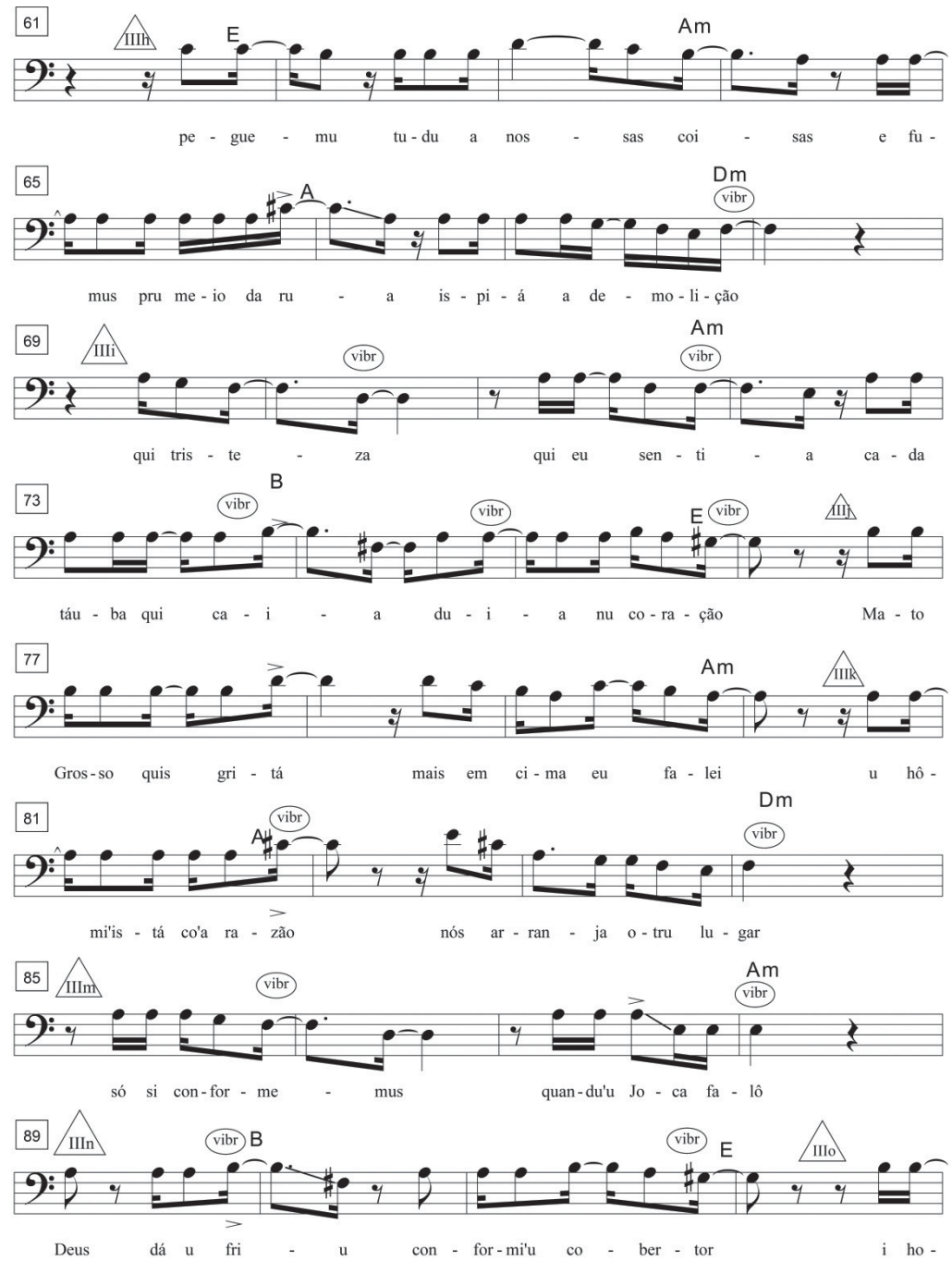

$-3-$ 


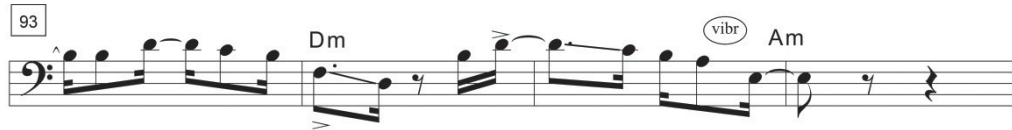
ji nóis pe - ga bá - ia nas gra - ma du jar - dim

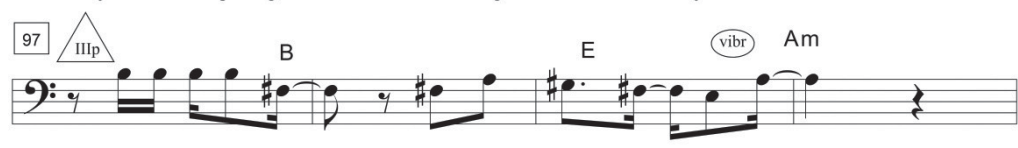
i prá is -que - cê nóis can - te - mus as - sim
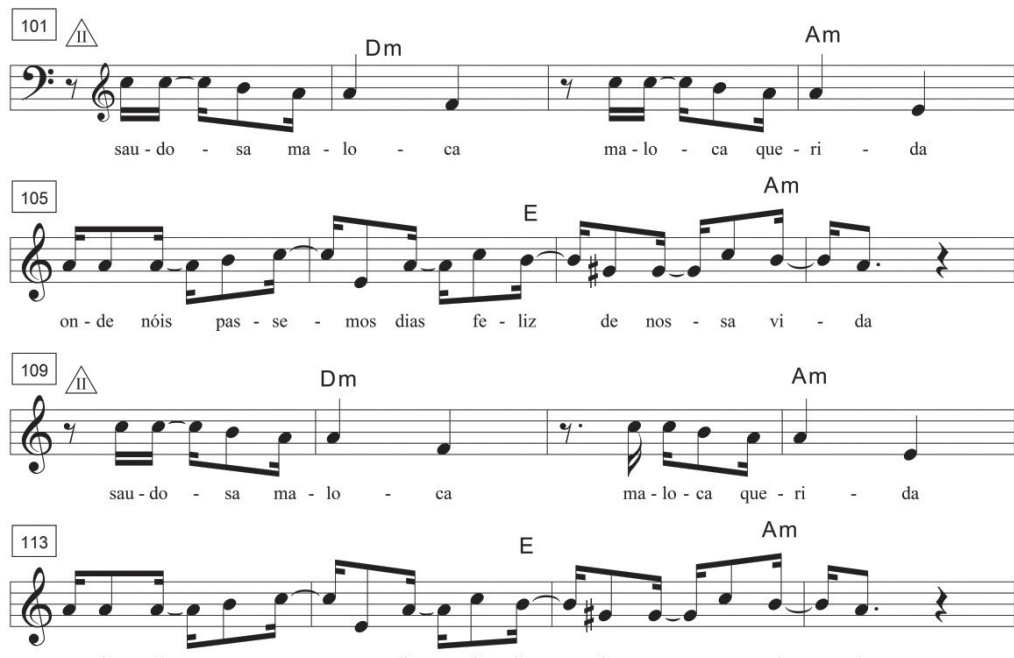
on- de nóis pas - se - mo dias fe - liz de nos - sa vi - da
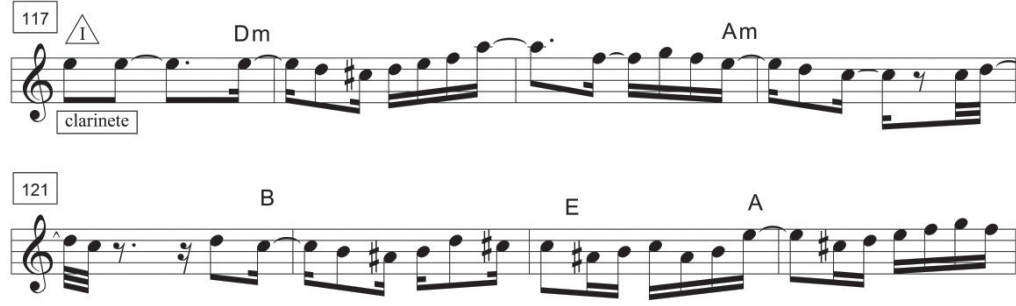

$-4-$ 


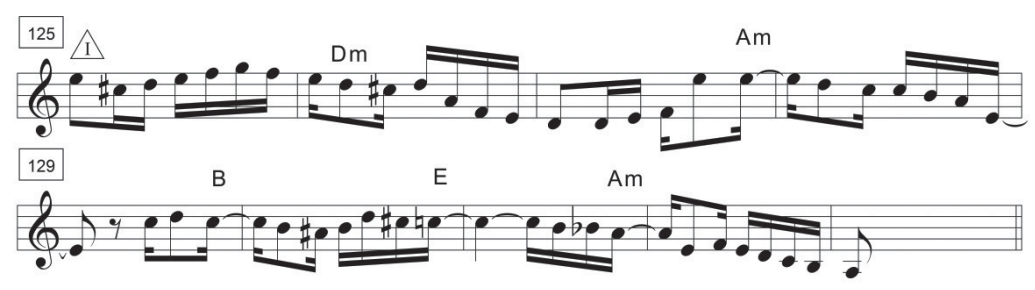


Uma transcrição de trabalho é por natureza prescritiva, de forma alguma tendo a pretensão de ser descritiva - o que nenhuma transcrição obtém ser -, para recordar um texto clássico da Etnomusicologia (Seeger, 1958). Ela é isso, com certeza, e sem dúvida que ela pode ser de fundamental valia - e, então, como acontece muitas vezes, menos é mais - na análise e compreensão de uma peça musical. Acrescento que uma transcrição musical é algo como um mapa, que - senão no caso narrado por Borges no conto, "Do rigor na ciência"- nunca será o território que procura representar, mas, exatamente, tão somente o representa. Qualifico abaixo alguns símbolos usados na transcrição ${ }^{14}$ :

a) As letras (A, B, C, etc) indicam os acordes. Um $\underline{M}$ depois de uma letra representa um acorde maior; $\mathrm{um} \underline{\mathrm{m}}$, menor.

b) Os números romanos inscritos em triângulos identificam as seções da transcrição conforme minha análise.

c) Aqueles inscritos em quadrados assinalam os compassos na transcrição.

d) A abreviatura "vibr", inscrita numa elipse, indica "vibrato".

e) Um traço descendente $(\backslash)$ sinaliza glissando.

f) O sinal (>) significa acentuação forte.

Em seguida, apresenta-se uma transcrição - igualmente de trabalho, sem nenhum rigor linguístico, pois - da letra da canção de acordo com a versão de 1951. Nota-se que antes da entrada da parte cantada da canção, assim como ao final, quando o coro se cala, ouve-se uma longa intervenção ao clarinete com acompanhamento do regional (I na partitura, na introdução, compassos 1-16; na conclusão, 177-132) ${ }^{15}$. A transcrição:

(introdução ao clarinete, com regional)

Saudosa maloca (coro em uníssono, clarinete continua)

Maloca querida

Onde nóis passemos

Dias feliz de nossa vida

Saudosa maloca

Maloca querida

Onde nóis passemo 
Dias feliz de nossa vida

Se o sinhô num tá lembrado (canto Adoniran solo)

Dá licença de contá

Qui aqui onde agora está

Esse edifíciu ártu

Era uma casa véia

Um palacete assobradadu

Foi aqui seu moçu

Qui eu, Mato Grossu e o Joca

Construímus nossa maloca

Mais um dia

Nem queru me lembrá

Chegô os hômis co'as ferramenta

Qui o donu mandô derrubá

Peguemu tuda a nossas coisas

E fumus pru meio da rua

Ispiá a demolição

Qui tristeza

Qui eu sentia

Cada táuba qui caía

Duía nu coração

Mato Grosso quis gritá

Mais em cima eu falei:

“O hômi istá co'a razão

Nois arranja otru lugar"

Só si conformemus

Quandu o Joca falô:

“Deus dá o friu

Conformi o cobertor"

E hoji nóis pega báia

Nas grama do jardim

E prá isquecê

Nois cantemus assim:

"Saudosa maloca (coro em uníssono) 


\author{
Maloca querida \\ Onde nós passemos \\ Dias feliz de nossa vida \\ Saudosa maloca \\ Maloca querida \\ Onde nóis passemo \\ Dias feliz de nossa vida" \\ (conclusão instrumental: clarinete e regional)
}

Logo a seguir, e para efeito de contrastação imediata com o arranjo de 1951, apresento uma transcrição da letra conforme o arranjo de 1955, dos Demônios. Nessa transcrição, assinalei em negrito as partes da letra mais notavelmente diferentes em relação ao primeiro arranjo. Como já adiantei, não estudarei aqui o arranjo de 1955, senão de modo breve e com interesse comparativo em relação ao de 1951. Segue a transcrição:

(entrada instrumental breve)

"Ya gas cas cas cu la (coro em uníssono, com acompanhamento instrumental)

Da ra ra ra la ia (solo)

Ya gas cas cas cu la (coro em uníssono)

Da ra ra ra la ia (solo)

Ya gas cas cas cu la cun can (coro em uníssono)

[ sonoridade de confusão (cachorro latindo, etc.)]

Ya gas cas cas cu la (coro em uníssono)

Da ra ra ra la ia (solo)

Ya gas cas cas cu la (coro em uníssono)

Ya gas cas cas cu la cun can

Cun can cun can cun can cun can

Se o sinhô num tá lembrado (coro em uníssono)

Dá licença de contá

Qui aqui aonde agora está

Esse edifíciu artu

Era uma casa véia

Um palacete assobradadu 
Foi aqui seu moçu

Qui eu, Mato Grossu e o Joca

Construimus nossa maloca

Mais um dia

Nois nem pode se alembrá

Veio os hômis co'as ferramenta

Qui o donu mandô derrubá

Peguemu tuda a nossas coisas (coro com vozes diferentes)

E fumus pru meio da rua

Apreciá a demolição

Qui tristeza (coro em uníssono)

Qui nois sentia

Cada táuba qui caía

Duía nu coração

Mato Grosso quis gritá (coro com vozes diferentes)

Mais em cima eu falei:

“Os hômis istá co'a razão

Nois arranja otru lugar"

Só si conformemus (coro em uníssono)

Quandu o Joca falô:

“Deus dá o friu

Conformi o cobertor"

E hoje nóis pega páia

Nas grama do jardim

E prá esquecê

Nois cantemus assim:

"Saudosa maloca

Maloca querida

Din din donde nós passemos

Dias feliz de nossa vida

Saudosa maloca (coro com vozes diferentes)

Maloca querida

Din din donde nós passemo

Dias feliz de nossa vida" 


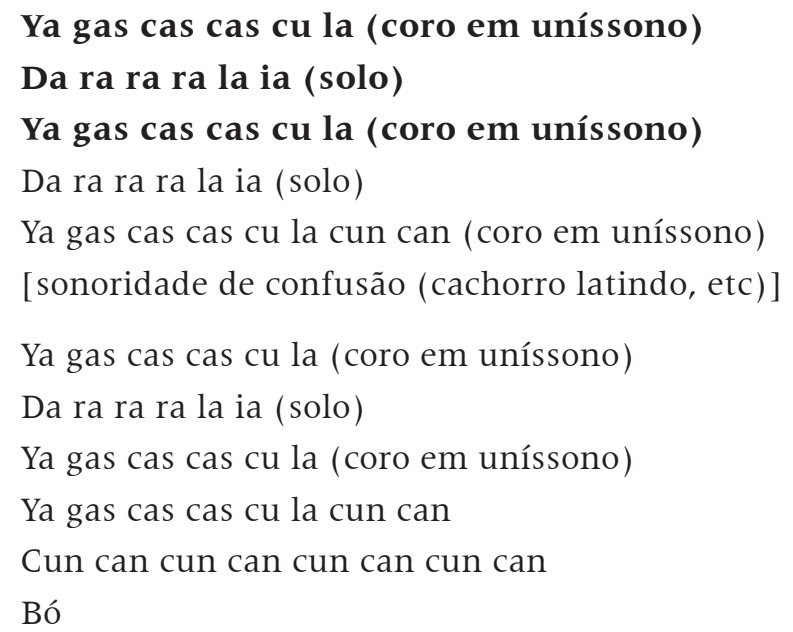

Entre as diferenças mais notáveis entre os dois arranjos estão aquelas das suas seções introdutória e conclusiva. No primeiro, essas seções são realizadas por formação puramente instrumental, clarinete e regional (compassos 1-16 e 117-132). Não há canto nem letra ali. No segundo, na seção introdutória, de começo ouve-se o regional sozinho, mas durante pouco tempo, logo em seguida ele se fazendo ouvir acompanhando o coro masculino que, em uníssono, canta sonoridades que sugiro serem onomatopeias das vozes dos instrumentos musicais em ação. Ao final dessa configuração (trato ainda da seção introdutória do segundo arranjo), escutam-se o que parecem ser onomatopeias de latidos caninos, resultando naquilo que na transcrição chamei "sonoridade de confusão". Eu não duvidaria estar aqui frente a um referente ao encontro dos heróis (Eu, Mato Grosso e Joca) com “os hômis", encontro este, nesta versão, de forma alguma resignado por parte dos heróis, diferentemente do que se passa na primeira versão. A seção conclusiva, ainda do segundo arranjo, é quase idêntica à introdutória, apenas nela não se escutando o regional tocando sozinho, mas sempre acompanhando o coro ${ }^{16}$.

Antes de passar à análise do arranjo de 1951, exploro um pouco mais sua contrastação com o de 1955. Faço isso, entre outros, por um interesse em especial: o da confrontação entre as categorias composição e arranjo, intermediadas por aquela de autoria. Esta última categoria, segundo a imensa maioria dos autores - e não somente aqueles citados 
neste texto -, marca positivamente a primeira categoria e negativamente a segunda.

A partir do sucesso do arranjo dos Demônios - não só da Maloca, mas também de O Samba do Arnesto (também de 1955), Iracema (1956), e outras canções posteriores, como Tiro ao Álvaro(1965) e Trem das Onze $(1965)^{17}$-, as relações entre Barbosa e o grupo tornaram-se difíceis, para não dizer amargas ${ }^{18}$. O motivo do amargor era a disputa pela autoria da causação do sucesso das canções, especificamente,no presente caso, da Saudosa Maloca. Como disse desde o começo, a versão de 1951 da Maloca, com arranjo de Nelson Miranda e tendo como cantor o próprio compositor,foi obscura, diz-se mesmo que foi um fracasso por ter vendido ao que parece apenas duas cópias (Cavenaghi, 2010, p. 5). Note-se que a versão dos Demônios, de 1955, tudo indica ter vendido 90.000 cópias (Mugnairi Júnior, 2003, p. 80), a partir dessa versão, o grupo e o próprio Adoniran, como compositor e letrista, se tornaram publicamente notáveis ${ }^{19}$. A contenda, então, se instalou, como se pode ver por este texto, constante do então sítio dos Demônios, até pelo menos novembro de 2006:

Adoniran é conhecido como compositor das músicas dos Demônios, mas a coisa não foi bem assim... No início, quando os Demônios gravaram as primeiras músicas de Adoniran, o compositor reclamou bastante porque não gostou das modificações feitas pelo grupo, mas, devido ao grande sucesso que estas músicas tiveram, Adoniran deu plena liberdade ao grupo para os acréscimos dos nossos conhecidos "Quais, Quais, Quais" e humor especial, que tanto caracterizam os Demônios quanto Adoniran. Durante toda a parceria, os Demônios sempre fizeram modificações nas músicas de Adoniran, que sempre reclamou mas acabava cedendo ao ver o sucesso que as músicas obtinham. Adoniran era, sem dúvida, um grande compositor, mas os Demônios da Garoa foram fundamentais, e são também co-autores não reconhecidos da maioria das músicas do compositor paulista. Esta célebre união foi uma das mais importantes da música brasileira, e vai ter sempre um lugar especial para os amantes da MPB. Tem gente que, indiretamente, diz que os Demônios faziam palhaçadas com as músicas de Adoniran. Mal sabem eles que, se não fossem os 
Demônios da Garoa, Adoniran certamente não teria a fama que tem. Ele, inclusive, também adotou o jeito "demoniogaroístico" de ser depois que viu o sucesso de suas músicas na voz dos Demônios. Todo aquele jeito especial e original de cantar é obra do grupo. ${ }^{20}$

Observa-se a seguir, por outro lado, o teor da reação de Celso Campos Júnior, um dos principais estudiosos de Barbosa, a uma reportagem recente (2010) sobre o compositor que, na abordagem da disputa em consideração, toma o partido dos Demônios:

Por desconhecimento histórico (quero crer), os atuais integrantes dos Demônios da Garoa - nenhum dos quais remanescentes da década de 1950, origem da parceria - têm incorrido em repetidos erros sobre a concepção do estilo que consagrou Adoniran Barbosa. Embarcando nesse equívoco, a reportagem veicula a afirmação de que "o estilo 'narfabeto' foi ideia dos Demônios", supostamente inaugurado com a gravação de "Saudosa Maloca" pelo conjunto, em 1955. O quinteto teria transformado "tábua em 'tauba"" e exagerado nos erros de português, e Adoniran, somente depois disso, teria começado a incorporar termos como "nóis fumus" em seus sambas. Bem, na primeira versão de "Saudosa Maloca", de 1951 - quatro anos antes da gravação dos Demônios, portanto -, Adoniran já cantava "edifício arto", "casa véia", "construímo", "peguemo tuda nossas coisas", "cada tauba que caía", etc. Nessa mesma época, outras músicas, como "Conselho de Mulher" ("pogréssio, pogréssio..."), gravada por Adoniran em 1952, já maltratavam propositalmente o português. Querer atribuir o estilo "narfabeto" aos Demônios é, portanto, caso grave de apropriação indébita. ${ }^{21}$

Observa-se como a disputa em análise toma exclusivamente o falar narfabeto como elemento causador do sucesso da Maloca e outras canções, o primeiro depoimento defendendo a ideia até de coautoria dos Demônios, o segundo buscando evidenciar que a origem do citado falar estava no próprio Barbosa - comojá a epígrafe a este texto deixa claro - e que a posição contrária se trataria de um caso grave de apropriação indébita $^{22}$. Nenhuma das partes da contenda, porém, dáse conta de que o falar narfabeto é apenas um lado da questão, o uso 
de onomatopeias, entre tantos outros - como aqueles ligados à parte propriamente musical dos arranjos -, sendo outros, bem diferentes ${ }^{23}$.

O que eu pretendia com essa excursão à contrastação dos dois arranjos, por meio da confrontação entre suas letras, levadas também em conta, porém - nas seções introdutória e conclusiva - em suas partes musicais, parece ter ficado saliente: primeiro, no universo das concepções expressas na contenda anterior - concepções nativas - a primeira versão do samba, um arranjo de Nelson Miranda, parece ter a sua condição de arranjo neutralizada, sendo equacionada com a própria composição de Barbosa; segundo, nesse mesmo universo que produz essa neutralização e equacionamento, a problemática da autoria é fortemente colocada em foco, pela entrada em cena da segunda versão, um arranjo dos próprios Demônios (1955) ${ }^{24}$.

Por outro lado, sobre a cadeia de conceitos pertinentes ao conceito de arranjo e sobre a natureza aspectual para a qual ele aponta, o que foi trabalhado até aqui parece também ter deixado claro como o conceito de versão é parente do de arranjo ${ }^{25}$. Um arranjo, assim, constituiria uma modalidade específica, diferente de todas as demais, de elaborar um determinado material básico ou preexistente.

O arranjo de Nelson Miranda pode ser segmentado da seguinte maneira ${ }^{26}$ :

I, 1-8 (parte de 9): introdução instrumental (clarinete e regional) I', 9-16 (parte de 17): idem(diferente de I)

II, 17-24: refrão (coro feminino em uníssono, clarinete e regional)

II, 25-32: idem (repetição)

III: a, 32-35 (parte de 36): estrofes (canto solo masculino, clarinete e regional)

b, 36-39 (parte de 40): idem

c, 40-44: idem

d, 45-48: idem

e, 49-52: idem

f, 53-55 (parte de 56): idem

g, 56-60 (parte de 61): idem

h, 61-68: idem

i, 69-75 (parte de 76): idem 
j, 76-79 (parte de 80): idem

$\mathrm{k}, 80-84$ : idem

l, 85-88: idem

m, 89-91 (parte de 92): idem

n, 92-96: idem

o, 97-100: idem

II, 101-108: refrão (coro feminino em uníssono, clarinete e regional); idêntico aosdois anteriores

II, 109-116: idem/idem

I' ',117-124 (parte de 125): conclusão instrumental (clarinete e regional)

I' ', 125-132 (parte de 133): idem

Resumindo, trata-se da seguinte sequência de segmentos:

$$
\text { (I, I' III,II),(III, III' } \left.\ldots . . . I^{\mathrm{n}}{ }^{\mathrm{n}}\right),\left(\mathrm{II}, \mathrm{II}, \mathrm{I}^{\prime \prime}, \mathrm{I}^{\prime}{ }^{\prime \prime}{ }^{\prime}\right)
$$

Em um nível de redução maior, essa sequência pode ser expressa através de uma forma espelhar ternária do tipo A B A, onde A tem dois segmentos temáticos (tipologicamente, I e II), um deles (I) subdividido em quatro subtemas, dois a dois (I, I' [na introdução] e I' ', I' ' [na conclusão]), e B compõe-se de 15 segmentos temáticos bem mais curtos, similares a motivos. Trata-se, esse arranjo, de uma forma musical complexa, onde a repetição se dá apenas no refrão - lugar por excelência dela -, todas as demais seções sendo diferentes entre si, apesar de, evidentemente, poderem ter essa diferença reduzida através de uma análise mais fina, o que, entretanto, não farei aqui.

A introdução e a conclusão deste arranjo (I, I' e I' ', I' ', compassos 1-8, 9-16 e 117-124, 125-132), quanto à sua parte solo a cargo do clarinete, não são triviais. Trata-se de quatro segmentos, todos diferentes entre si, longos, somando 32 (de um total de 132) compassos, cerca de $1 / 4$ do arranjo. Não é só, o clarinetista que os toca, de maneira virtuosística - provavelmente tendo-os composto -,está presente de maneira igualmente notável, realizando contracantos, durante toda a extensão do arranjo, contaminando-o, por assim dizer, como um todo com o seu páthos. Tudo isso somado concorre para a elevação da contribuição do clarinete ao arranjo a uma posição de pri- 
meiríssima hierarquia, comparável somente à posição do cantor solista e compositor ${ }^{27}$. Quanto à parte desses segmentos a cargo do regional, trata-se de um acompanhamento rotineiro, envolvendo violão de seis cordas, cavaquinho, pandeiro e tam-tam ${ }^{28}$.

O tônus geral da introdução e conclusão do arranjo e de todo o restante da intervenção do clarinete nele é a tristeza, a nostalgia, suas características evocando o universo de tópicas denominado época de ouro (Piedade, 2001, [2012?]; Bastos, 2008) ${ }^{29}$. A expressão época de ouro é em geral aplicada na literatura para identificar o período da história da música popular brasileira que vai do fim dos 1920, com a incepção da gravação elétrica e a popularização do rádio, até o final dos 1940. Trata-se de uma época rica e diversificada, compreendendo nomes como os de Noel Rosa, Ary Barroso, Ataulfo Alves e Carmen Miranda ${ }^{30}$.Esse é também o período da primeira geração de arranjadores da música popular no país, incluindo Radamés Gnattali, Pixinguinha, Gaó, Lyrio Panicali e Leo Peracchi ${ }^{31}$.

Quanto ao universo das tópicas citado, ele tem como característica forte o emprego de floreios melódicos, marcados pelo uso de apojaturas, grupetos e outras formas de ornamentação, e de certos padrões - incluindo aproximações por grau, conjunto e cromáticas - e desenhos melorrítmicos similares às célebres "baixarias", tão marcantes, essas últimas, no mundo do choro (Bastos, 2008). Segundo os autores referidos, tais características contribuem para constituir o universo de tópicas em toque como um referente ao clima de lirismo ligado a gêneros musicais brasileiros antigos como a modinha, a valsa, a música de seresta e o choro, provocando no ouvinte um sentimento de nostalgia - eu diria, de saudade - em relação ao Brasil do passado. (Piedade, 2011) ${ }^{32}$

Uma inspeção medianamente atenta à transcrição do arranjo em análise evidencia a presença das marcas citadas, conforme abaixo (os números referem-se a compassos):

Apojatura: 1-2; 3-4; 117-118

Mordente: 121-122 (superior)

Grupetto: 118-119 (inferior)

Aproximação por grau conjunto: 2-3; 4-5 
Aproximações cromáticas: 6-7; 7; 8; 15-16

Padrões com caráter e função das "baixarias": 2-3; 16-17; 127$128 ; 133-134$

É com o clima de nostalgia construído pelos dois segmentos da introdução que o arranjo atinge a parte II (compassos 17-24, com repetição ipsis litteris em 25-32), somando 16 compassos (32 com as repetições, também ipsis litteris, em 101-108/109-116). Trata-se do refrão da canção, realizado pelo coro feminino em uníssono, acompanhado pelo regional e tendo, como já registrado, também presente os contracantos a cargo do clarinete. Note-se que os quatro segmentos II - como aqueles tipologicamente I - somam um total também de 32 compassos, aproximadamente $1 / 4$ do arranjo.

Nessa seção - o refrão -, o núcleo central de significação da letra, a cargo do coro feminino em uníssono, é a saudade, o que, em tudo por tudo, é não somente compatível, mas continuativo com tudo o que veio antes, centrado - como se viu - na nostalgia. Note-se que o clarinete, no refrão, continua a atuar da mesma maneira com que realizou todo o começo do arranjo. Igualmente, o regional. O coro que realiza o refrão tem um desempenho sem maiores inflexões. Note-se que na letra, há apenas duas pequenas ocorrências do falar narfabeto: "onde nóis passemos", com a variante "onde nóis passemo", e "dias feliz de nossa vida". Na parte musical, o refrão se repete ipsis litteris nas duas vezes em que ele ocorre, na introdução e na conclusão.Quanto ao regional, ainda no refrão, ele mantém a mesma levada e tônus com que veio até aqui, evidenciando-se uma vez mais como um acompanhamento rotineiro. Esse desempenho dir-se-ia, em geral, neutro do refrão, por definição a seção de uma canção que a ancora - de onde ela sai, para onde ela vai -, traz um elemento de contraste em relação à introdução e conclusão instrumentais e à parte do canto solo, ambas muito diversificadas.

O canto de Adoniran constitui a segunda parte mais longa do arranjo de Miranda, ocupando 68 compassos, um pouco mais da metade de sua extensão. Ele só não é mais longo que a intervenção do clarinetista, que, como disse, atravessa todo o arranjo. Barbosa conta com o acompanhamento do regional - que aqui se mantém, 
como tenho dito, rotineiro - e com a continuação da intervenção,de caráter nostálgico - conforme visto, tipo época de ouro -, do clarinete. Trata-se de um canto simultaneamente econômico e elaborado em termos expressivos, o que é consequência da produção, pelo cantor, de determinadas inflexões na voz em determinadas partes de sua intervenção, o que anotei na transcrição. Essas inflexões são feitas através de distinções prosódicas resultantes de acentuações, fortes no caso (> na transcrição), vibratos (abreviatura vibr., dentro de uma elipse) e glissandos $(\backslash)$. Em alguns momentos, surpreende a ausência de inflexão, tipicamente em pontos onde a letra alcança picos dramáticos. Isso pode resultar para o ouvinte - ela mesma, a ausência de inflexão - como inflexão.O canto de Adoniran não é óbvio nem derramado, flutuando entre a tristeza e a alegria contidas ${ }^{33}$.

Na primeira estrofe (compassos 32-44), saliento a ausência de inflexão na entrada, quando o narrador pede licença a "sinhô"- alguém em posição hierárquica superior - para fazer sua narrativa. $\mathrm{O}$ tema da memória, envolvendo recordação e esquecimento, é então ali lançado - "Se o sinhô num tá lembrado/Dá licença de contá" (32-36). Verifica-se desde aí que se trata, a Maloca, de uma narrativa histórica. As inflexões a seguir na estrofe recaem em sílabas tônicas da letra, em um trecho em que a função harmônica é a dominante com sétima (A7) da subdominante (Dm) da tonalidade da canção (Am).Vale considerar que a acentuação (>) nas sílabas tônicas aí - e em todas as demais posições anotadas - se mostra efetivamente uma inflexão e, não, uma obviedade, na medida em que não ocorre simplesmente em todas as tônicas de palavras, mas apenas naquelas em que o cantor seletivamente a produz. Sugiro que tal acentuação aponta para um destaque que o cantor deseja realizar na palavra em que ela ocorre. São as seguintes as sílabas com inflexão: "tá" de "está" (37-38, >), "ar" de "artu" (39-40, vibr), "vé" de "véia" (41-42, >), "ce" de "palacete" (42-43, vibr.). No momento da resolução na subdominante (Dm, 4344), um glissando atinge as duas sílabas finais de "assobradadu", a penúltima sendo a tônica. A alternância entre o velho ("véia", "palacete", "assobradadu") e o novo ("está", "artu") aqui se evidencia como um dos objetos centrais da narrativa. 
A segunda estrofe (45-80) também tem início com uma fala do narrador na direção de "sinhô", chamado agora "seu moço" ("Foi aqui seu moço", 45-46), "moçu" cantado em glissando. Em seguida, o narrador relata que foi "aqui", na casa "véia", que ele (Eu), Mato Grosso e Joca, os heróis da narrativa, instalaram o seu reduto - a maloca aí figura ser um reduto, espaço político não somente esquivo, mas também concorrencial em relação ao que lhe é exterior. Nesse trecho (47-48), já de volta para o campo harmônico da tônica (Am), Joca também é cantado em glissando. A sílaba "sa" de "nossa" é então acentuada $(>, 51)$, embora não seja tônica, isso acontecendo sobre um acorde de dominante da dominante (B) que deságua na dominante (E) em "lo" de "maloca" (51-52), "lo" sendo cantada com >, "loca" em vibrato. A letra em seguida alcança um de seus momentos mais dramáticos, de novo quando a função harmônica é a dominante com sétima (A7) - agora também com uma nona, menor - da subdominante (Dm): "Mais um dia (53-54) nem (54) queru me lembrá" (55-56, Dm). Essa nona (a nota si bemol sobre a palavra "nem") é cantada enfaticamente, antecedida que é por uma pausa e seguida por outra - inflexão feita sem nenhum dispêndio senão as próprias pausas. A estrofe, então, se fecha: "chegô os hômis co'as ferramenta"(57-58, Am), "menta" em glissando. Adoniran em seguida recita, de maneira contida, documental: "qui o donu mandô derrubá" (57-80). Não há inflexão aqui, senão o próprio recitativo, onde "mandô" é cantado na dominante (E), "derrubá" na tônica (Am). Há uma fina dialética nas duas primeiras estrofes entre os usos do glissando e do vibrato, o primeiro ocupando quase sempre a posição de finalização de verso, o vibrato ocorrendo em sílabas pertencentes a palavras marcadas pelo cantor na letra.

A terceira estrofe (63-76) é dominada pelo uso quase exclusivo do vibrato. Com exceção do que se passa no verso, "cada táuba qui caía" (73-74), entoado na dominante da dominante (B), onde o vibrato se soma à acentuação forte (>) em "ía" de "caía", todas as demais inflexões são somente vibrato. Nessa estrofe narra-se a expulsão dos heróis de seu reduto, quando vão para a rua (65-66) - cantada na dominante $(\mathrm{A})$ da subdominante (Dm)- "ispiá a demolição"(67-68), 
frase onde a subdominante é atingida. A letra então logo recorda, lamentando, a tristeza (70) e a dor (74-75) - marcas profundas desta versão da Maloca - provocadas pela demolição do palacete naqueles que a espreitam. Aqui Barbosa narra na primeira pessoa do singular, sendo de notar que ele alterna as duas primeiras pessoas, usando a do plural quando fala em nome dos três heróis. As marcas acima notadas, - da tristeza e da dor - e da lamentação por elas - apelam em seguida para a resignação na estrofe seguinte (76-92). O grito impronunciado através do qual Mato Grosso sinalizaria resistir à demolição (76-77), entoado na dominante (E) e com acentuação forte em "tá" de "gritá", torna-se insubsistente no final, quando Joca (89-92) aciona a senha da resignação, de maneira proverbial: "Deus dá o friu" (89-90), "friu" sendo entoado na dominante da dominante (B), com acentuação forte, vibrato e glissando - aqui está a palavra mais marcada no canto -, "conformi o cobertor" (91-92), "cobertor" cantado na dominante (E), em vibrato. Há um forte investimento expressivo neste trecho, o uso do vibrato sendo um índice importante disso, apontando para uma especial sensibilização por parte do cantor.

A última estrofe é breve (94-100), de maneira, agora sim, exclusiva encontrando no vibrato sua marca expressiva. As inflexões ocorrem em "bá" de "báia" (94), entoado na subdominante (Dm), em "gra" de "grama" (94-95), "dim" de "jardim" (95-96) - cantado na tônica (Am) - e na finalização de "assim" (99-100), de novo na tônica, depois de uma passagem pela dominante da dominante (B) e dominante (E): "e prá isquecê (B) nois cante (E) mus assim (Am)". $\mathrm{O}$ apelo para a recordação do começo da narrativa aqui se vira para o esquecimento, seu tônus triunfante volvendo-se para o lado da derrota, tais as equações produzidas pela narrativa - entre a recordação e a vitória; e o esquecimento e a derrota. O que disse antes sobre o vibrato parece aqui se confirmar amplamente - trata-se de um sinal importante de sensibilização por parte do cantor.

Na gravação original, de 1951, aqui em uso e cuja referência discográfica foi antes anotada, Adoniran canta "báia" e, não, "páia", conforme é entoado na versão de 1955 dos Demônios, e em todas as demais versões que conheço da Maloca. Creio que posso assumir que 
Adoniran ali se enganou - "báia" levaria a cavalos; cavalos na Maloca? -, a expressão correta da letra sendo "pega páia", referindo-se à ação de limpar gramados de jardins. De acordo com Oliveira (2012), esses "Jardins", com maiúscula, referem-se a um conjunto de bairros - Jardim Europa, Paulista e outros - na zona oeste de São Paulo, integrados à malha urbana nos anos 1930. Eles passaram a ter posteriormente como habitantes integrantes de segmentos abastados, para os quais - na época referência desta canção (entre 1940 e 1950) - era costumeiro que a população pobre trabalhasse na função de jardineiro, entre outras ocupações. O canto de Barbosa parece, assim, ser uma narrativa histórica sobre transformações envolvendo as camadas baixas da cidade de São Paulo, uma narrativa cuja subjetividade não é nem um pouco derramada ou óbvia - constituindo-se, como disse, entre a tristeza e a alegria contidas -, e cuja finalização é resignadamente dolorida. Talvez aí esteja a raiz do propalado fracasso desta versão da Maloca, numa época em que São Paulo vivenciava o ufanismo econômico e a reinvenção de um determinado tipo de paulistanidade, tudo logo vindo a desembocar nas retumbantes comemorações do $4^{\circ}$ Centenário. Voltarei a isso.

Se, anteriormente, com base em uma análise que confrontou os dois primeiros arranjos da Maloca-através de seus contextos e letras, e levando em conta suas músicas - foi possível evidenciar que no universo das concepções nativas o primeiro arranjo teve a sua condição de arranjo neutralizada, passando a ser visto como a própria composição; e se, através da mesma análise, foi também possível tornar evidente que a problemática da autoria foi posta em foco no mesmo universo de concepções, pela entrada em cena do segundo arranjo; com base, agora, na análise medianamente detida, e integrada, da letra e da música do arranjo de Miranda, parece ser possível apontar para aquilo que dá sustentação a esses dois traços do citado universo de concepções, a saber: o cerne do arranjo em referência é o canto de Adoniran, que tem a sua assinatura indelével e um grande poder expressivo, pelo peso de sua interpretação.

É claro que se poderia argumentar que o peso maior do páthos do arranjo é dado pela onipresente nostalgia impressa pelo solo do 
clarinetista (ao que tudo indica, como já disse, seu próprio compositor). Mas esse clarinetista, seja quem tenha sido, mesmo que Abel Ferreira, além de não contar com a palavra - não sendo cantor, no caso cantautor -, não parece nunca ter sido um nome no contexto da Maloca, seu anonimato vis-à-vis sua onipresença no arranjo podendo bem dar a ideia de que, analiticamente, a rigor, o arranjo, com todas as suas interpretações intervenientes, é um universo todo ele autoral, como uma composição. Isso equivale a ver como uma ilusão - algo como uma zombaria - a diferença entre composição e arranjo, ilusão que move montanhas, entretanto, no mundo das mercadorias. Mas haverá algum outro mundo?

Se, igualmente, com base na já citada confrontação - e isso então no que se refere à cadeia de conceitos pertinentes ao conceito de arranjo e sobre a natureza aspectual para a qual ele acena -, deixei claro que o conceito de arranjo é parente do de versão (um arranjo, nesse sentido, constituindo uma modalidade específica, diferente de todas as demais do seu tipo, de elaborar um determinado material básico ou preexistente); agora, a análise medianamente detida da letra e da música do arranjo de Miranda parece evidenciar que essa aspectualidade resulta da articulação das várias interpretações ali presentes, assim, pois, o conceito de interpretação apontando para a própria atomicidade do de $\underline{\text { arranjo }}$ - o $\underline{\text { arranjo }}$, então, sendo o resultado da articulação entre as diversas interpretações que o integram.

O conceito de interpretação no campo de estudos sobre a música popular não sofre maior elaboração, como aquela que está presente no domínio que se ocupa de abordar a chamada música erudita, veja Laboissière (2007). Nesse trabalho do autor - para estudiosos e para músicos, não tanto para o público -, há uma forte distinção entre a partitura e a interpretação, a primeira sendo até reificada pela sua pretensa descritividade; o que de forma alguma acontece no primeiro campo, onde a interpretação é impensada como tal, evidenciando-se como, por assim dizer, um dado, obviado e naturalizado até, na medida em que a escrita musical não parece ser tomada,por estudiosos e músicos - o público simplesmente descurando-a -, como mais do que uma espécie de estenografia, veja Menezes Bastos (1995) para os dois casos. 
Para fechar esse círculo do presente texto, sobre a cadeia de conceitos pertinentes ao conceito de arranjo e sobre a natureza aspectual para a qual ele aponta, levando em conta que, de começo, aproximei o conceito de arranjo ao de versão, e que em seguida coloquei em contato o conceito de arranjo com o de interpretação - a primeira aproximação podendo levar a uma excursão à teoria da tradução, a segunda à da própria interpretação, no sentido geral -, seria profícuo articular essa cadeia conceptual com o conceito de transformação (inseparável, como se sabe, do de estrutura) em Lévi-Strauss. Deixo isso, porém, para o futuro, preferindo agora adiantar uma resposta à intrigante questão que faz parte do título deste texto: por que as canções têm arranjos? Respondo de chofre: as canções - desejo dizer, as canções em suas versões originais, aquelas que brotaram por primeiro da lavra de seus autores, logo desaparecendo - têm arranjo para que, constituídas como versões de segunda, terceira, etc., enésima ordens, possam trazer à luz um determinado universo de interpretações.

Sobre o propalado fracasso da primeira versão da Maloca - que teria vendido apenas duas cópias, conforme antes registrado -, vale começar dizendo que no mesmo ano de 1951 em que ele pretensamente se dava, o samba Malvina, também de Adoniran (letra e música), cantado pelos Demônios, ganhava o prêmio de primeiro lugar no concurso de músicas de carnaval da cidade de São Paulo. Em 1952, o mesmo aconteceu, com outro samba dele, de novo na interpretação dos Demônios, agora a letra sendo de Osvaldo Moles, letrista, mas muito mais conhecido como produtor de programas radiofônicos. Barbosa na época, pois, não era nenhum fracasso, como compositor e letrista, isso, por outro lado, num mercado musical orientado em grande parte para o Carnaval (Menezes Bastos, 2005). Como cantor, ele no máximo eventualmente não era ainda conhecido.

Ademais, Adoniran, desde pelo menos os começos dos anos 1940, era rádio ator cômico, trabalhando em várias emissoras, entre elas a Rádio Record. Seus personagens, entre os quais Zé Cunversa-presente já no 78rpm de lançamento da Maloca (veja nota 12) -, Jean Rubinet e outros, foram muito populares durante todos os anos 1940 e 1950, tendo sido criados por Moles, criador também dos programas, textos 
e tudo o mais dos grandes sucessos radiofônicos da dupla, inclusive do muito popular, "Histórias das Malocas", onde Adoniran era o Charutinho. Esse programa teve início em 1955, sob o impulso do sucesso da segunda versão da Maloca, tendo ficado no ar na Record até 1965. Barbosa e Moles dividiram a criação de vários sambas ${ }^{34}$. Quer dizer, o pretenso fracasso da Maloca, na versão de Adoniran foi algo de excepcional em sua já então bem-sucedida vida artística, na época tendo ele, porém, muito mais popularidade como ator de rádio do que como cantor. Popular também ele era, como se viu, como compositor e letrista no mercado carnavalesco, então o rei do mercado musical no Brasil ${ }^{35}$.

Ainda, por fim, sobre o propalado fracasso da primeira versão da Maloca - e, correspondentemente, o sucesso, quatro anos mais tarde, da segunda -, vale considerar que até o final dos anos 1950 o mercado do disco per se no Brasil tinha muito pequena magnitude. Poucas pessoas, na época, efetivamente compravam discos para ouvir em casa. Isso só vai se acontecer a partir dos anos 1960. O mercado musical no Brasil então era baseado no disco, sim, mas através do rádio, este, sim, o grande campeão de audiência, sobre o qual, infelizmente, os dados ainda são muito escassos, especificamente quanto a sua quantificação por gênero, cantor, compositor e tudo o mais. Além disso, o mercado tinha no cinema um meio também importante de disseminação ${ }^{36}$. Quer dizer, a comparação entre as duas primeiras versões da Maloca do ponto de vista de seu sucesso no mercado do disco parece ser, mais que tudo, uma projeção anacrônica.

A população do município de São Paulo deu um grande salto nos anos 1950, atingindo 3,5 milhões de pessoas. A grande responsável por isso foi a expansão industrial, que impulsionou correntes migratórias com origem principalmente no Nordeste e no interior do estado, atraídas por um sempre crescente mercado de trabalho, particularmente nos setores fabril e de construção civil. Com a implantação na segunda metade da década da indústria automobilística no ABC, houve um importante crescimento econômico na região metropolitana, com fortes consequências nos planos demográfico, urbanístico e arquitetônico, entre outros, em toda a sua área de influência. Nos dois últimos planos, observa-se que houve uma drástica mudança na cidade de São Paulo - 
para ficar apenas nela -, tipicamente, mas não apenas, em sua região central, que passou a ser cada vez mais ocupada por arranha-céus, os “edifíciu(s) artu(s)"da Maloca $^{37}$. A ideologia ufanista do progresso passou a marcar de maneira decisiva a paulistanidade - aquela dos contentes, por assim dizer -, sendo amplamente apropriada pelo discurso político. A Maloca, como procurei evidenciar, é uma narrativa sobre esse processo histórico e suas consequências para as camadas baixas, uma narrativa cuja finalização é, entretanto - resignadamente sim, mas com certeza - dolorida, revelando uma paulistanidade dos descontentes, na contramão de todo ufanismo desenvolvimentista.

O regionalismo paulista, aqui subsumido pelo termo "paulistanidade", tem existência pelo menos desde o século XVIII. Como todo regionalismo, a paulistanidade supõe uma generalização da condição do ser regional, no caso paulista e paulistano, e uma avaliação não somente positiva sua, mas na imensa maioria das vezes superior às demais condições regionais brasileiras. No século XX, a paulistanidade tem um grande impulso a partir da década de 1930, com as revoluções de 1930 e 1932. Nessa época, nota-se a importância fundamental das obras de intelectuais como Paulo Duarte, Guilherme de Almeida e Menotti del Picchia e outros (Cerri, 1998). Na década de 1950, - época de incepção da Maloca - ela sofre uma forte inflexão, tornando-se mercadoria, o que se evidencia com especial clareza na época dos festejos ligados ao quarto centenário de São Paulo, em 1954 (Godoy, 2011). A partir daí, é que o slogan sobre a cidade como aquela que "não pode parar" tornou-se um apelo com forte eco local - paulista e paulistano - e nacional. A narrativa de Adoniran Barbosa fica na corrente contrária disso, articulando-se com um universo discursivo significativo do mundo intelectual paulista e paulistano que, no campo da música popular, entretanto sem nenhum acento erudito, antecipa muito das posturas críticas da chamada vanguarda paulista ${ }^{38}$. O propalado fracasso da Maloca na versão cantada por Adoniran ou - é efetivamente o que entendo - sua obscuridade no mercado fonográfico ipsis litteris tem essa inscrição crítico-interpretativa: tristeza, dor, lamentação, resignação. Essa versão acabou transformando-se na versão de referência da Maloca, dando início a uma hoje longa sequência de versões, entre as 
quais está aquela dos Demônios, de 1955, marcado pela jocosidade e pelo desdém, fabricados por uma musicalidade da irrisão - os arranjos existem para tornar possível a explicitação articulada de universos diferentes de interpretações.

\section{Notas:}

1 Este texto foi concebido em 1996, tendo como temática o mundo das relações da canção popular com a constituição da alteridade e a transgressão. Sua segunda versão é de 2002, que teve como núcleo temático a construção do herói pela canção flutuando entre a rebeldia e a resignação. Em 2006, escrevi sua terceira versão. Então, ele já se desenhava tendo como tema o arranjo na música popular, fulcro da presente versão, cuja escrita concluí em dezembro de 2012, quando era Pesquisador Visitante no Departamento de Antropologia da Universidade de Montréal. Obrigado a Robert Crépeau e a Bob White pela troca de ideias e gentilezas em Montréal. Sou grato também a Silvia de Oliveira Beraldo, pelas conversas sobre a temática do arranjo. Devo a ela a ideia seminal de que a canção na música popular é conhecida através de seus arranjos, somente existindo devido a eles. Obrigado, por fim, a Acácio Tadeu de Camargo Piedade, Allan de Paula Oliveira, Kaio Domingues Hoffmannn e María Eugenia Domínguez pelos comentários. Sou o único responsável pelo texto.

2 Professor do Departamento de Antropologia da Universidade Federal de Santa Catarina. Coordenador do MUSA (www.musa.ufsc.br), Núcleo de Estudos Arte, Cultura e Sociedade na América Latina e Caribe. Pesquisador 1B do CNPq. Pesquisador do Instituto Brasil Plural.

3 Note-se, porém, que se na abordagem desse autor, o mito de referência é arbitrariamente referencial, pois, tão somente, o primeiro é considerado, no caso do arranjo, o material básico é referencial historicamente, sendo o original de todos os arranjos possíveis - suas transformações, conforme Lévi-Strauss - de uma determinada canção, tema, melodia, peça vocal e/ou instrumental. Em 2013, trabalho intensamente o emprego do conceito de mito de referência ao campo musical.

4 Obrigado a Samuel Araújo por me indicar este trabalho e a Pedro Aragão pela gentileza de seu envio.

5 Conforme 1999 para sua versão em inglês.

6 Apelido de Osvaldo Gogliano (São Paulo 1910 - Rio de Janeiro 1962), compositor, arranjador e pianista. Para dados em geral sobre a música popular brasileira, veja Marcondes (1999) e o Dicionário Cravo Albin da Música Popular Brasileira em: <http:// www.dicionariompb.com.br/>.

7 Compositor, cantor e violonista (Rio de Janeiro 1910-1937).

8 Veja Seitel (1999) para um excelente estudo etnográfico feito com base no modelo dialógico de Bakhtin. Meu texto de 2007 expressa minha compreensão desse modelo e seu emprego no domínio musical.

9 Adoniran Barbosa foi registrado como João Rubinato. Quando tinha dez anos, sua data de nascimento foi adulterada para 1910, para que ele pudesse trabalhar legalmente. Então, a idade mínima para uma criança poder trabalhar era de doze anos. Sobre a vida e a obra de Barbosa, conforme Bento (1990), Campos (2004), Gomes (1987), Moura e Nigri (2002), Mugnani Júnior (2002), Rocha (2002) e os demais textos adiante referidos. Conforme Carmos (2001) para um estudo sobre 
a canção aqui estudada.

10 Dicionario EletrOnicoHouaiss da Língua Portuguesa, versão 1.0, dezembro de 2001 (copyright do Instituto Antonio Houaiss). Produzido e distribuído pela Editora Objetiva Ltda.

11 Ambos os arranjos estão disponíveis no sítio do Instituto Moreira Salles (<http:// ims.uol.com.br/>, acessado em 05/10/2012).

12 O arranjo de 1951 está na face B do disco de 78rpm da Continental 16468 (matriz 11335-1), nela o samba intitulando-se, não, Saudosa Maloca, mas Saudade da Maloca, ao que parece por erro da gravadora. Ali, ao nome de Adoniran Barbosa, segue-se, entre parênteses, o de Zé Cunversa, nome de um de seus personagens cômicos como radio ator. Também ali o conjunto é chamado de Nelson Miranda e seu Conjunto (Mugnaini Jr, 2002, p. 81-203). Trata-se de um regional, integrado, ao que consigo ouvir e como disse antes, por violão de seis cordas, cavaquinho, pandeiro e tam-tam. Nelson Miranda, além de diretor de conjunto e arranjador, era cantor, compositor, cavaquinista e bandolinista (veja o Dicionário Cravo Albin de Música Popular Brasileira, <http://www.dicionariompb.com.br/>, acessado em 8/2/2012). Obrigado a Maria Beraldo Bastos pela escuta do arranjo de 1951 e pela sugestão de que o clarinetista (também compositor e saxofonista) nele presente pode ter sido Abel Ferreira (Minas Gerais 1915 - Rio de Janeiro 1980). O clarinete ocupa uma posição absolutamente distinta durante todo o arranjo.

13 Este arranjo do samba, de 1955, ocupa a face A do 78rpm da Odeon 13855 (matriz 10553), ali os Demônios sendo identificados como conjunto vocal (veja Mugnaini Jr, 2002, p 81-203). Os Demônios têm origem nos anos 1940, com o nome Grupo do Luar, sendo ainda hoje atuantes e constituindo-se no grupo voco-instrumental de música popular mais antigo do mundo, conforme registro, a partir de 1994, no Livro Guinness dos Recordes. O grupo tem tido muitas formações desde suas origens. Em 1955, ela era a seguinte: Arnaldo Rosa (afoxé e voz), Antônio Gomes Neto (vulgo Toninho, violão tenor), Francisco Paulo Galo (percussão, tam-tam), Arthur Bernardo (violão) e Cláudio Rosa (pandeiro).

${ }^{14}$ Prefiro qualificar a transcrição musical e, não, simplesmente, reclamar dela.

15 O clarinete e o regional permanecerão tocando durante todo o arranjo.

16 Sobre a ideia de onomatopeias das vozes dos instrumentos musicais em geral, devo-a a Patrício de Lavenère Bastos. Sobre a versão dos Demônios, obrigado a Allan de Paula Oliveira, Paulo Freire, Roberto Corrêa e Silvia de Oliveira Beraldo. Com eles, conversei especialmente sobre o fato de a versão em tela nunca ter me parecido ser um samba de acordo com o paradigma do Estácio (Sandroni, 1997, 2001 ), tendo uma marca indelevelmente paulista, ligada possivelmente ao universo da moda de viola. É claro que isto carece de análise, o que, infelizmente não poderei fazer agora. Devo dizer sobre isso e o mais que aqui se encontra que sou o único (ir)-responsável por este texto.

17 Sobre os Demônios, conforme Ângelo (2009).

18 Sobre o amargor dessas relações, veja Ângelo (2009) e também sua entrevista em http://www.portalsaofrancisco.com.br/alfa/adoniran-barbosa/adoniram-2.php, sítio acessado em 7/10/2012. Nesta, o autor em consideração diz, em resposta ao entrevistador sobre como era a relação entre os Demônios e Barbosa: "Péssima. Uma pena. E tudo por conta de desacertos financeiros. 'Trem das Onze' até hoje é a marca registrada do Demônios" ( sublinhado meu).

19 Conforme adiante, a avaliação da primeira versão como um fracasso deve ser relativizada, considerando a magnitude reduzida do consumo doméstico de discos nos 
anos 1950 no Brasil, então ouvidos tipicamente através do rádio. Por outro lado, Adoniran, nos referidos anos, já era um rádio ator cômico muito popular.

${ }^{20} \mathrm{Em}<\mathrm{http}$ //www.geocities.com/demoniosdagaroa/pagina4.htm >, acessado em 13/11/06. Este link - no qual constava o texto do qual faz parte o trecho citado não é mais acessível hoje, mas ainda é possível rastreá-lo, buscando-o através do referido trecho no Google. Sublinhados meus.

${ }^{21}$ Veja em: <http://revistaepocasp.globo.com/Revista/Epoca/SP/0,,EMI136921-15389,00-CARTAS.html>. Trata-se de uma crítica severa do estudioso a uma reportagem sobre Barbosa saída em Época de São Paulo em abril de 2010 (acessada em 07/10/2012). Sublinhados meus.

22 Sobre o falar narfabeto em tela, conforme Cândido (1975).

${ }^{23}$ É curioso como os trechos da introdução e clausura da versão dos Demônios - onde se encontram as onomatopeias em comentário - não parecem ser considerados letras fixas, tipicamente pelo público, sendo muitas vezes cantados, em tom jocoso, como: "Jogue as calças (ou "as cascas") prá lá/jogue as calças prá lá/jogue as calças prá lá/meu bem...". Nessa paródia, parece que quem fala é uma mulher, para um homem, nos primórdios de um encontro amoroso.

24 Sobre a autoria na música popular, há uma longa literatura, veja, por exemplo, Frith (1986), uma boa parte dela buscando articular-se com o conhecido texto de Foucault sobre a função-autor (2001 [original de 1969]). A propriedade sobre os textos - literários no caso de Foucault - é para este a primeira marca da referida função. No campo da música popular na Inglaterra, observe-se como na segunda década do século XX não constituía ponto pacífico a remuneração das letras das canções, veja Frith (1989).

25 Sobre o conceito de versão - e também do de arranjo -, conforme Cano (2011) e Domínguez (2011).

${ }^{26}$ Neste esquema, os algarismos romanos apontam seções do arranjo, os arábicos, compassos, tudo de acordo com a transcrição.

27 Conforme dito anteriormente, é bem possível que ao clarinete neste arranjo tenha estado efetivamente Abel Ferreira, conforme sugerido por Maria Beraldo Bastos.

28 Às vezes me parece também soar no regional, alternando com o cavaquinho, um bandolim. Recordo que Miranda tocava os dois instrumentos. Noto que a minha audição analítica do regional é precária.

29 Para a teoria das tópicas em termos gerais e especificamente para o campo da música brasileira (popular e erudita), conforme os três textos citados e mais Piedade (2012a, 2012b). Obrigado a Acácio pelo envio de alguns de seus textos e a ele e Marina Beraldo Bastos, por algumas trocas de mensagens sobre a questão das tópicas. Sou, porém, o único e exclusivo responsável pela minha análise.

${ }^{30}$ Conforme meu texto de 2005, para dados sobre esse período na história da música popular brasileira.

31 Veja em: <http://maestrorochasousa.blogspot.ca/2009/08/o-arranjo-na-musica-popular-brasileira.html $>$, acessado em 27/10/2012.

32 Deixando para estudos futuros a sua análise, adianto que o arranjo dos Demônios de forma alguma me parece evocar o universo das tópicas épocas de ouro, estando possivelmente muito mais próximo daquele que os autores referidos denominam brejeiro, relacionado com a malandragem.

33 Sobre o encontro da tristeza com a alegria em Barbosa, recordo que em 1980 ele foi homenageado com o disco "Adoniran Barbosa - 70 Anos" (EMI-Odeon, número 064 422868). A capa do disco, de autoria de Elifas Andreato, trazia o desenho de um 
palhaço chorando, ao que o diretor da Odeon teria dito a Andreato que Adoniran não entenderia esse desenho como referência a ele. Isto fez o capista desenhar um palhaço mais sóbrio. Meses depois, Barbosa ter-lhe-ia dito: "Elifas, eu sou esse palhaço triste aqui, e não o alemão que você pôs na capa do disco. " (conforme As memórias sentimentais de São Paulo, título da resenha de Francisco Quinteiro Pires ao livro de Matos [2007], em<http://www.controversia.com.br/index.php?act = textosfid $=1791>$, acessado em: 04/1 1/2-12, sublinhados meus). Veja Matos (2007) para um estudo abrangente sobre Barbosa. Sobre outra modalidade desse encontro entre a tristeza e a alegria na música popular no Brasil - um marca, aliás, profunda de seu caráter -, conforme o caso de Noel Rosa, igualmente dono de um cantar nem um pouco óbvio ou derramado, veja Menezes Bastos (1996).

34 Para estas informações, conforme Mugnani (2002).

35 Sobre a vida de rádio ator de Barbosa e o rádio em geral em São Paulo, conforme Maia (2007), Pereira (2001) e Silva (2010), e grande parte da literatura já referida sobre a sua vida e obra.

${ }^{36}$ Veja meu texto de 2005 sobre o mercado musical brasileiro nos anos 1950.

37 Veja em: <http://smdu.prefeitura.sp.gov.br/historico_demografico/1950.php>, acessado em 12/12/2012 para dados sobre a história demográfica do município de São Paulo. Conforme Durham (1973) para um clássico da antropologia sobre as migrações para São Paulo.

38 Veja meu texto de 2005 para um estudo detido sobre a música - e a cultura em geral - nas comemorações do $4^{\circ}$ Centenário.

\section{Referências}

ÂNGELO, Assis. Pascalingundum! Os Eternos Demônios da Garoa. São Paulo: edição do autor, 2009.

ARAGÃO, Paulo. Pixinguinha e a gênese do arranjo musical brasileiro (19291935). Rio de Janeiro: Universidade do Rio de Janeiro (UNIRIO). Dissertação de Mestrado em Música, 2001.

BAKHTIN, Mikhail M. The Problem of Speech Genres. In: EMERSON, C.; HOLQUIST, M. (Ed.), Speech Genres and Other Later Essays. Austin: University of Texas Press, 1986. p. 60-102.

BASTOS, Marina Beraldo. Tópicas na música popular brasileira: uma análise semiótica do choro e da música instrumental. Florianópolis: Universidade do Estado de Santa Catarina. Trabalho de Conclusão de Curso, 2008.

BENTO, Maria Aparecida. Um cantar paulistano. São Paulo: Universidade de São Paulo. Dissertação de Mestrado em Música, 1990. 2 v.

BESSA, Virgínia de Almeida. A Escuta singular de Pixinguinha: história e música popular no Brasil dos anos 1920 e 1930. São Paulo: Alameda, 2010.

BOYD, Malcolm. Arrangement: Grove Music Online (Ed.) L. Macy. 2006. Disponível em: < http://www.oxfordmusiconline.com/public/book/omo_ gmo $>$. Acesso em: 8 maio 2006. 
BRITO, Iêda M. Samba na cidade de São Paulo: um exercício de resistência cultural. São Paulo, Editora da Universidade de São Paulo, 1986.

CAMPOS JÚNIOR, Celso de. Adoniran: uma biografia. São Paulo: Globo, 2004.

CANDIDO, Antonio. (texto da contracapa) LP Adoniran Barbosa. Odeon SMOFB 3877, Direção Musical de José Briamonte, 1975.

CANO, Rubén López. Lo Original de la versión. De la ontología a la pragmática de la versión em la música popular urbana, Consensus, 16: 5782, 2011. Disponível em: <http://www.academia.edu>. Acesso em: 24 nov. 2012.

CARMO, Maurício M. do. Dá Licença de contar: quatro interpretações de "Saudosa Maloca" na construção da narrativa paulistana. In: CARMO, Maurício M. do. Ao Encontro da palavra cantada: poesia, música e voz, 2001. p. 257-166.

CAVENAGHI, Airton José. 2010. Saudosa Maloca e o Patrimônio Cultural Imaterial Constituído por Adoniran Barbosa. In: XX ENCONTRO REGIONAL DE HISTÓRIA: HISTÓRIA E LIBERDADE. ANPUH/SP UNESP-Franca.De6 a 10 de setembro de 2010. Anais..., Franca, 2010. CDROM. Disponível em: < http://www.anpuhsp.org.br/sp/downloads/CD\%20 XX\%20Encontro/PDF/Autores\%20e\%20Artigos/Airton\%20Jos\%E9\%20 Cavenaghi.pdf > . Acesso em: 25 nov. 2012.

CERRI, Luis Fernando. Non Ducor, Duco: a ideologia da paulistanidade e a escola. Revista Brasileira de História, 18 (36): 115-136, 1998. Disponível em: $<$ http://www.scielo.br/scielo.php?pid=S010201881998000200007 sscript $=$ sci_arttext $>$. Acesso em: 13 dez. 2012.

DOMÍNGUEZ, María Eugenia. Versiones, apropriación e intermusicalidad en el Rio de la Plata. Antropologia em Primeira Mão, 126: 5-19, 2011.

DURHAM, Eunice. A Caminho da Cidade. São Paulo: Perspectiva, 1973.

FRITH, Simon. Art x Technology: the strange case of popular music. Media, Culture and Society, 8: 263-279, 1986. Disponível em: <http://dx.doi.org/10.1 177/016344386008003002>. Acesso em: 12 dez. 2012.

. Why do Songs Have Words? Contemporary Music Review, 5: 77-96, 1989. Disponível em: < http://www.tandfonline.com/toc/gcmr20/current\#. UnGL-PnNXr8>. Acesso em: 12 dez. 2012.

GODOY, João Miguel Teixeira de. 2011 . Identidade e Regionalismo Paulista: trajetória e mutações. In: XXVI SIMPÓSIO NACIONAL DE HISTÓRIA (ANPUH), Anais... São Paulo, julho de 2011. Disponível em: $<$ http://www.snh2011.anpuh.org/resources/anais/14/1300653320_ ARQUIVO_Anpuh201ltextocompleto2.pdf>. Acesso em:12 dez. 2012. 
LEME, Bia Paes. (Org.). Pixinguinha na Pauta: 36 arranjos para o programa "O Pessoal da Velha Guarda". São Paulo: Instituto Moreira Salles/ Imprensa Oficial do Estado de São Paulo, 2010.

FOUCAULT, M. Original de 1969. Qu'est-ce qu'un auteur? Foucault: Dits et écrits I, 1954-1975. Paris: Gallimard, 2001.

GOMES, Bruno. Adoniran: um sambista diferente. Rio de Janeiro: Fundação Nacional de Arte (FUNARTE), 1987.

HERZOG, G. The Yuman Musical Style. Journal of American Folklore, XLI: 183-231, 1928. Disponível em: http://www.jstor.org >. Acesso em: $12 \mathrm{dez}$. 2012.

. A Comparison of Pueblo and Pima Musical Styles. Journal of American Folklore, XLIX: 283-417, 1936.

LABOISSIÈRE, Marília. Interpretação Musical: a dimensão recriadora da “comunicaçao" poética. São Paulo: Annablume, 2007.

MAIA, Marta Regina. A Diversidade Musical do Rádio Paulistano nas Décadas de 30 a 50. In: V CONGRESSO DE HISTÓRIA DA MÍDIA, São Paulo. Anais... São Paulo, 2007.

MARCONDES, Marcos Antônio. (Ed.). Enciclopédia da música popular brasileira: erudita, folclórica e popular. 2. ed. São Paulo: Art Editora/ Publifolha, 1999.

MATOS, Maria Izilda. A Cidade, a noite e o cronista: São Paulo e Adoniran Barbosa. São Paulo: Edusc, 2007.

MENEZES BASTOS, Rafael José de. A Festa da jaguatirica: uma partitura crítico-interpretativa. São Paulo: Universidade de São Paulo. Tese de doutorado em Antropologia Social, 1990.

. Esboço de uma teoria da música: para além de uma antropologia sem música e de uma musicologia sem homem. Anuário Antropológico 1993,p. 9-73, 1995.

. A origem do samba como invenção do Brasil (por que as canções têm música? Revista Brasileira de Ciências Sociais, 31: 156-177, 1996.

. The origin of samba as the invention of Brazil (why do songs have music?). British Journal of Ethnomusicology, 8: 67-96, 1999.

. Brazil. In: SHEPHERD, John; HORN, David; LAING, Dave. (Org.). Caribbean and Latin America, Continuum Encyclopedia of Popular Music of the World. Londres/New York: Continuum, p. 212-248, 2005. v. 2. 
. Para uma antropologia histórica das relações musicais Brasil/ Portugal/África: o caso do fado e de sua pertinência ao sistema de transformações Lundu-Modinha-Fado. Antropologia em Primeira Mão, 102, 2007.

. A Festa da jaguatirica: uma partitura crítico-interpretativa. Florianópolis: Editora da Universidade Federal de Santa Catarina, 2013. MOURA, Flávio; NIGRI, André. Adoniran: se o senhor não tá lembrado. São Paulo: Boitempo Editorial, 2002.

MUGNAINI Jr., Ayrton. Adoniran: dá licença de contar. São Paulo: Editora 34, 2002.

OLIVEIRA, Allan de Paula. Comunicação pessoal, 2012.

PEREIRA, João Batista B. Cor, profissão e mobilidade: o negro e o rádio de São Paulo. São Paulo: Editora da Universidade de São Paulo, 2001. 1 a edição de 1967.

PIEDADE, Acácio Tadeu de Camargo. Perseguindo fios da meada: pensamentossobre hibridismo, musicalidade e tópicas. Per Musi, 23: 103$112,2011$.

. Música e retoricidade. In: IV ENCONTRO DE MUSICOLOGIA DE RIBEIRÃO PRETO - USP/Campus Ribeirão Preto, 29-31/08/12, Anais... Ribeirão Preto, 2012a.

. Rhetoricity in the music of Villa Lobos: musical topics in Brazilian early XXth-century music. Comunicação apresentada à International Conference on Music Semiotics in Memory of Raymond Monelle. The University of Edinburgh, 26-28 de outubro de 2012b.

. Música Popular, expressão e sentido: comentários sobre as tópicas na análise da música brasileira. [2012?]. Disponível em:<http://www.ceart. udesc.br/revista_dapesquisa/volumel/numero2/musica/musica_popular. pdf $>$. Acesso em: $1^{\mathrm{o}}$ out. 2012.

ROCHA, Francisco. Adoniran Barbosa: o poeta da cidade - trajetória e obra do radioator e cancionista, os anos 50. São Paulo: Ateliê Editorial, 2002.

SANDRONI, Carlos. Le Samba à Rio de Janeiro et le Paradigme de 1’Estácio. Cahiers de Musique Traditionelles, 10: 153-168, 1997.

. Feitiço decente: transformações do samba no Rio de Janeiro (1917-

1933). Rio de Janeiro: Jorge Zahar; Editora UFRJ, 2001.

SCHULLER, Gunther. Arrangement: Grove Music Online (Ed). L. Macy. 2006. Disponível em: <http://www.oxfordmusiconline.com/public/book/ omo_gmo $>$. Acesso em: 8 maio 2006. 
SEEGER, Charles. Prescriptive and Descriptive Music Writing. Musical Quarterly, XLIV,(2): 184-195, 1958.

SEITEL, Peter. The Powers of genre: interpreting haya oral literature. New York: Oxford University Press, 1999.

SILVA, Vandré Aparecido Teotônio da. Saudade da Maloca: representações e rememorações no centenário de Joao Rubinato. In: XX ENCONTRO REGIONAL DE HISTÓRIA: HISTÓRIA E LIBERDADE. ANPUH/SP UNESP-Franca. De 6 a 10 de setembro de 2010. Anais..., Franca, 2010. CD-ROM.

SZENDY, Peter. Écoute: une histoire de nos oreilles. Paris: Les Éditions de Minuit, 2001.

Recebido em 08/08/2013

Aceito em 15/11/2013 